Liturgia Sacra 24 (2018), nr 1, s. 229-240

DOI: $10.25167 / \mathrm{LitS} / 24(2018) 1 / 229-240$

ANDRZEJ GŁadysZ

Instytut Muzykologii KUL

\title{
Ojciec profesor Józef Ścibor (30 I 1930 - 3 VI 2017) - student, pracownik i świadek historii \\ Instytutu Muzykologii \\ Katolickiego Uniwersytetu Lubelskiego Jana Pawła II
}

6 czerwca 2017 r. ostatnią ziemską drogę na tuchowski cmentarz redemptorystów odbył w licznej asyście o. prof. dr hab. Józef Ścibor CSsR - znawca teorii i historii muzyki średniowiecza, specjalista w zakresie chorału gregoriańskiego.

Jako że postać o. Ścibora zapisała się na trwale w historii Katolickiego Uniwersytetu Lubelskiego Jana Pawła II, a zwłaszcza Instytutu Muzykologii, działającego w strukturze Wydziału Teologii, nie sposób w rocznicę śmierci muzykologa nie odnieść się do jego wkładu w rozwój lubelskiego środowiska muzykologicznego ${ }^{1}$.

Prezentowany szkic ma charakter kronikarski i jest tylko przyczynkiem do studiów nad biografią i dorobkiem naukowym oraz artystycznym zmarłego redemptorysty. Powstał na podstawie dokumentów zachowanych w Archiwum Uniwersyteckim KUL oraz o kronikę Koła Naukowego Studentów Muzykologii, oraz Instytutu Muzykologii, zdeponowane w Bibliotece IM KUL.

\section{Młodość}

By przywołać młodzieńcze lata, warto oddać głos samemu bohaterowi niniejszego tekstu: „Urodziłem się 20 stycznia 1930 roku w Kobierzynie jako syn robotników Pawła i Heleny z pochodzenia wieśniaków. W czasie okupacji po

[Brak aut.], Ścibor Józef, ,Additamenta Musicologica Lublinensia. Rocznik Instytutu Muzykologii Katolickiego Uniwersytetu Lubelskiego" 2 (2006), s. 36-37. 
skończeniu Szkoły Podstawowej zacząłem studium w zakresie szkoły średniej w trybie nauczania tajnego u oo. Redemptorystów w Krakowie. W czasie okupacji straciłem ojca. W r. 1947 wstąpiłem do Zgromadzenia OO. Redemptorystów i w tymże Zgromadzeniu zdobyłem wykształcenie średnie, odbyłem 2-letni kurs filozofii chrześcijańskiej i 4-letni kurs Teologii w Wyższym Seminarium. W roku 195519 VI otrzymałem święcenia kapłańskie. W latach 1956-1960 odbyłem studia w Instytucie Muzykologii Kościelnej na Katolickim Uniwersytecie Lubel$\operatorname{skim}(\ldots)^{m}$.

\section{Student}

O. Józef Ścibor figuruje na liście pierwszego rocznika studentów muzykologii kościelnej - nowego kierunku wprowadzonego od roku akademickiego 1956-1957 na Wydziale Teologii KUL ${ }^{3}$. Spośród 13 kandydatów, oprócz o J. Ścibora przyjętych zostało 6 osób: ks. Jan Chwałek, ks. Edward Hinz, Leon Kałużyński SVD, ks. Kazimierz Pasionek, ks. Jerzy Pikulik oraz s. Benigna Helena Racka (felicjanka). Kadrę stanowili: ks. prof. Hieronim Feicht (wstęp do muzykologii), ks. mgr Karol Mrowiec (harmonia, repetytorium z harmonii, zagadnienia z zasad), ks. mgr Wojciech Lewkowicz (semiologia gregoriańska, chór, emisja głosu), ks. mgr Tadeusz Miazga (chorał gregoriański, ćwiczenia z chorału), ks. dr Wacław Schenk (liturgika), Marian Ochalski (solfeż) oraz Barbara Dąbrowska (fortepian) ${ }^{4}$. Powstały równocześnie dwie klasy organów: ks. K. Mrowca i M. Ochalskiego. O. Ścibor dopiero w marcu 1957 r. dołączył do pierwszej z nich ${ }^{5}$. Podczas studiów odznaczał się dużym zaangażowaniem, uzyskując niemal same oceny bardzo dobre ${ }^{6}$.

30 maja 1960 r. studenci zagrali swój ostatni egzamin z organów. Kronikarz zaznaczyła: „O. Józef Ścibor robi starania w Wyższej Szkole Muzycznej w War-

2 Archiwum Uniwersyteckie KUL (dalej AU KUL), Akta Personalne A-887, Ścibor Józef Paweł, cz. 1, Życiorys. Wieczyste śluby zakonne Józef Ścibor złożył 2.08.1953 (tamże, cz. 2, Pismo Prowincjała Redemptorystów z 1.10.1999).

3 Zob. S. ŁAch, Kronika Wydziału Teologicznego 1944-1968, w: M. Rechowicz I IN. (red.), Księga Jubileuszowa 50-lecia Katolickiego Uniwersytetu Lubelskiego, Lublin 1968, s. 143-157; por. B. BARTKowski, 25 lat Instytutu Muzykologii Kościelnej KUL, „Biuletyn Informacyjny Katolickiego Uniwersytetu Lubelskiego" 11 (1982), nr 1/2, s. 93-100.

${ }^{4}$ Biblioteka Instytutu Muzykologii KUL (dalej BIM KUL), Kronika Instytutu Muzykologii Kościelnej przy Wydziale Teologicznym KUL, t. 1: 1956-1967, bpg.

5 Tamże.

${ }^{6}$ AU KUL, sygn. A-887, Ścibor Józef Paweł, cz. 1, Dyplom ukończenia studiów wyższych. 
szawie, aby dostać się do klasy organowej p. prof. F. Rączkowskiego"7. Wysiłek uwieńczony został sukcesem i po ukończeniu klasy organowej złożył na KUL-u egzamin licencjacki i pracę na temat Autentyczność cysterskich traktatów muzycznych z XII w. Miało to miejsce 25 maja 1965 r., a dzień później odbył się egzamin magisterski. Obu komisjom przewodniczył ks. prof. Andrzej Krupa - dziekan Wydziału Teologii ${ }^{8}$.

\section{Wykladowca i naukowiec}

Po ukończeniu studiów w warszawskiej PWSM oraz obronie magisterium na KUL-u przed o. Ściborem pojawiła się możliwość zatrudnienia na macierzystej uczelni. Inicjatorem tego angażu był ks. dr Karol Mrowiec, który w opinii na temat kandydata notował: „Stwierdzam, że zarówno zdobyte kwalifikacje fachowe, jak i zalety moralne rokują nadzieje na jego dalszy rozwój naukowy i artystyczny. Wobec powyższego wnoszę prośbę o zaangażowanie go na asystenta IMK". Zgodę na zatrudnienie przez Katolicki Uniwersytet Lubelski wyraził także prowincjał redemptorystów, z zaznaczeniem, że zainteresowany „będzie prowadził również zajęcia w Wyższym Seminarium Duchownym w Tuchowie i musi je pogodzić"10. Rada Wydziału zaaprobowała plany kadrowe na posiedzeniu 13 września 1965 r., a decyzja została zaakceptowana przez władze Uniwersytetu ${ }^{11}$.

I tak 1 października 1965 r. o. mgr Józef Ścibor rozpoczął zajęcia dydaktyczne w Instytucie Muzykologii Kościelnej na etacie asystenta. W ciągu pierwszych trzech lat zostały mu powierzone takie przedmioty, jak: kontrapunkt (1965-1966), analiza i praktyka harmonii oraz organy (1965-1968). Z kolei od roku akademickiego1968-1969 dołączył do nich wykład i ćwiczenia z harmonii gregoriańskiej. W opinii napisanej pod koniec roku akademickiego ks. dr Karol Mrowiec notował o podwładnym: „(...) podjął wszystkie zlecone mu zajęcia dydaktyczne, wykonując je sumiennie i z zapałem (...). Sądzę, że

\section{Tamże.}

${ }^{8}$ AU KUL, Akta Studentów sygn. T-15639, Ścibor Józef Paweł, Protokót z egzaminu licencjackiego 25.05.1965; tamże, Protokót z egzaminu magisterskiego 26.05.1965.

9 AU KUL, sygn. A-887, Ścibor Józef Paweł, cz. 1, Opinia do zatrudnienia autorstwa ks. K. Mrowca z 1965.

${ }^{10}$ Tamże, List Prowincjała Redemptorystów do Wydziału Télogicznego KUL z 6.07.1965. Działalność dydaktyczną w WSD Redemptorystów w Tuchowie o. Ścibor prowadził do $1995 \mathrm{r}$.

${ }_{11}$ Tamże, List Rady Wydziału Teologii do Rektoratu z 13.09.1965. Zob. także: BIM KUL, Kronika Instytutu Muzykologii Kościelnej, t. 1: 1956-1967, bpg. 
ma warunki na dobrego pedagoga, zwłaszcza w zakresie gry organowej i harmonii praktycznej"12.

Z czasem zainteresowania i wiedza o. Ścibora były wykorzystywane w prowadzeniu kolejnych przedmiotów, m.in.: harmonii modalnej, harmonii praktycznej, historii harmonii i kontrapunktu, metodyki badań nad chorałem gregoriańskim, paleografii chorału gregoriańskiego, a także proseminarium, seminarium magisterskiego oraz doktoranckiego i innych zajęć.

Jako świadek historii Instytutu przygotował tekst pamiątkowy z okazji 50-lecia KUL dotyczący studiów muzykologicznych ${ }^{13}$. Należy przy tym zaznaczyć, że już w początkowym okresie pracy na uczelni o. Ścibor dużo chorował, co było przyczyną urlopów zdrowotnych, m.in. w semestrze zimowym 1968-1969 oraz na początku semestru letniego 1969-1970 ${ }^{14}$.

Zdolności o. Ścibora zostały szybko dostrzeżone. Powierzono mu przygotowanie Scholi Cantorum na II Zjazd Profesorów Muzyki Sakralnej w Gnieźnie, który odbył się 21-22 kwietnia 1967 r. ${ }^{15}$ Z kolei wiosną 1970 r. o. mgr Ścibor kierował wielogłosowymi śpiewami liturgicznymi studentów muzykologii w ramach Tygodnia Liturgicznego ${ }^{16}$.

Młody naukowiec angażował się również w wydarzenia naukowe na uczelni oraz poza nią. Uczestniczył m.in. w dyskusji po odczycie dr Barbary Andrzejczak z Poznania na temat Polskich pieśni kolędowych z przełomu XVII i XVIII w. w źródłach rękopiśmiennych, który miał miejsce 22 kwietnia 1972 r. ${ }^{17} \mathrm{~W}$ dniach 16-18 grudnia 1977 r. wystąpił podczas konferencji muzykologicznej w Warszawie ${ }^{18}$. Z okazji 25-lecia Instytutu Muzykologii Kościelnej powierzono mu zaszczytne zadanie zaprezentowania podczas sesji naukowej 26 listopada 1981 r. sprawozdania z ćwierćwiecza działalności jednostki ${ }^{19}$. O. Ścibor należał do grona współorganizatorów XVI Ogólnopolskiej Konferencji Muzykologicznej na temat: Chorat gregoriański w polskiej kulturze muzycznej, która odbyła się 3 grudnia 1982 r., Wygłosił

12 AU KUL, sygn. A-887, Ścibor Józef Paweł, cz. 1, Opinia ks. K. Mrowca z 12.05.1969.

13 J. ŚciBor, Muzykologia Kościelna na Katolickim Uniwersytecie Lubelskim, „Roczniki Teologiczno-Kanoniczne" 15 (1968), z. 3, s. 67-84.

${ }_{14}$ AU KUL, sygn. A-887, Ścibor Józef Paweł, cz. 1, List o. Ścibora do Dziekanatu WT $z$ 22.02.1970.

15 BIM KUL, Kronika Instytutu Muzykologii Kościelnej, t. I: 1956-1967, bpg.

16 Tamże, Kronika Instytutu Muzykologii Kościelnej KUL, t. III: 1969-1974, bpg.

17 Tamże, bpg.

18 Oprócz o. dra Józefa Ścibora udział wzięli (ks. doc. dr hab. K. Mrowiec, ks dr B. Bartkowski i ks. dr J. Chwałek). Zob.: Kronika działalności Koła Naukowego I.M.K., t. IV: 1974-1980, s. 173.

19 Kronika działalności Koła Naukowego I.M.K., t. V: 1981-1983, bpg. 
on wprowadzenie merytoryczne oraz referat Struktury modalne śpiewów Alleluja do roku $1100^{20}$. Angażował się również w działalność artystyczną i duszpasterską muzykologów. 23-24 listopada 1974 r. wziął m.in. udział w koncertach w Bielsku-Białej, gdzie dziękował za ofiarność na rzecz KUL, a także odprawił Mszę św. dla miejscowego chóru ${ }^{21}$.

W trakcie wieloletniej pracy starał się wspierać aktywność studencką, m.in. uczestnicząc w spotkaniach Koła Naukowego Studentów IMK ${ }^{22}$, czy przygotowując instytutowych organistów w klasie organów specjalnych. W 1982 r. odnotowany został przez kronikarza jako Opiekun Studentów IMK KUL ${ }^{23}$. Zgodnie z własnymi sprawozdaniami, funkcję taką sprawował w latach 1981-1995²4. Później zaczęto powoływać opiekunów dla poszczególnych roczników studiów. Z kolei w latach 1985-1998 był kuratorem Chóru Akademickiego KUL.

W roku akademickim 1972-1973 o. mgr Ścibor został awansowany na starszego asystenta. Przechodził także kolejne egzaminy wymagane do przewodu doktorskiego. Zdał kolejno: filozofię (5 czerwca), egzamin kierunkowy (16 czerwca $)^{25}, 8$ listopada 1973 r. zaliczył język francuski, a 3 marca 1976 r. także język niemiecki ${ }^{26}$. Ważnym momentem $\mathrm{w}$ jego życiu zawodowym była obrona pracy doktorskiej: Chorat Cystersów w świetlne zabytków XII w. Komisja zebrała się 16 czerwca 1973 r. Promotorem pracy był prof. Józef Chomiński, zaś recenzentami ks. doc. Karol Mrowiec i doc. Anna Czekanowska ${ }^{27}$.

Po uzyskaniu stopnia naukowego doktora o. Ścibor ubiegał się o stanowisko adiunkta, które otrzymał 1 października 1977 r. W procesie awansowym uzyskał poparcie ówczesnego kierownika IMK, ks. prof. Karola Mrowca, który zanotował: „(...) ma dużo godzin dydaktycznych, prowadząc głównie przedmioty praktyczne, które są niezbędne dla realizacji programu dydaktycznego naszego Instytutu. Biorąc pod uwagę fakt, że o. dr Ścibor związał się od tylu lat z KUL-em i spełnił

\footnotetext{
20 Tamże, bpg.

${ }^{21}$ Kronika działalności Koła Naukowego I.M.K., t. IV: 1974-1980, s. 14-17.

22 Tamże, s. 198.

${ }^{23}$ Kronika działalności Koła Naukowego I.M.K., t. V: 1981-1983, bpg.

${ }^{24}$ Zob. m.in.: AU KUL, sygn. A-887, Ścibor Józef Paweł, cz. 1, Ocena działalności naukowodydaktycznej z 10.02.2000.

${ }_{25}$ AU KUL, sygn. T-15639, Ścibor Józef Paweł, Protokót egzaminu doktorskiego z filozofii 5.06.1973; tamże, Protokól doktorskiego egzaminu kierunkowego 16.06.1973.

${ }^{26}$ AU KUL, sygn. A-887, Ścibor Józef Paweł, cz. 1, Zaświadczenie z 8.11.1972; tamże, Zaświadczenie z 3.03.1976.

${ }^{27}$ Kronika Instytutu Muzykologii Kościelnej KUL, t. III: 1969-1974, bpg.
} 
wszystkie warunki wymagane do awansu na adiunkta - stawiam wniosek o powołanie go na to stanowisko"28.

Przedłużenie zatrudnienia w 1983 r. stało się okazją do kolejnych pozytywnych komentarzy pod adresem o. Ścibora. Kierownik Katedry, ks. prof. Jan Chwałek, odnotował, że „o. Ścibor jest długoletnim doświadczonym pracownikiem, w życie IMK wnosi dużo romantycznych zrywów i fantazji (...)", zaś ks. prof. Karol Mrowiec zauważył: „(...) w pracę dydaktyczną wkłada wiele energii i zapału" ${ }^{29}$.

Z kolei w 1984 r. ks. Mrowiec stwierdził, że „o. dr Józef Ścibor spełnia swe obowiązki dydaktyczne pilnie i wzorowo. Jak zawsze okazuje dużo entuzjazmu dla prowadzonych przez siebie zajęć”, a ks. Chwałek uzupełniał: ,jako opiekun studentów, o. Ścibor jest zaiste Dives in misericordie".

W trakcie blisko 40 lat pracy w IM KUL o. prof. Józef Ścibor doczekał się również grona studentów, którzy prowadzili własne badania pod jego okiem. Zostały one uwieńczone szeregiem prac dyplomowych, w tym 23 magisteriów i 3 doktoratów ${ }^{30}$.

Do dorobku naukowego o. Józefa Ścibora należy zaliczyć 3 książki, kilkanaście artykułów naukowych, kilkanaście haseł encyklopedycznych, głównie z zakresu chorału gregoriańskiego i teorii muzyki średniowiecznej. Ważnym elementem jego spuścizny są kompozycje religijne, głównie liturgiczne, w tym monodyczne i wielogłosowe kompozycje części stałych Mszy św., pieśni, nieszpory, akompaniamenty organowe oraz liczne aranżacje utworów sakralnych.

Za swoje zasługi został w 2000 r. doceniony Nagrodą im. św. Brata Alberta „za całokształt badań nad chorałem gregoriańskim - liturgiczną monodią Kościoła rzymskiego"31.

\section{Dyrektor}

29 listopada 1990 r. odbyło się kolokwium habilitacyjne zakończone nadaniem stopnia doktora habilitowanego nauk teologicznych w zakresie muzykologii. Jego pozytywny rezultat przyjął Senat Akademicki 26 stycznia 1991 r. oraz

28 AU KUL, sygn. A-887, Ścibor Józef Paweł, cz. 1, Ankieta pracownika z 9.02.1977.

29 Tamże, Ankieta pracownika z 1983.

${ }^{30}$ Szczegóły w Aneksie I.

${ }^{31}$ AU KUL, sygn. A-887, Ścibor Józef Paweł, cz. 2, Pismo Komitetu Nagrody św. Brata Alberta $z$ 19.12.2000. 
zatwierdziła Centralna Komisja ds. Tytułu Naukowego i Stopni Naukowych 28 października $1991 \mathrm{r}^{32}$

28 maja 1991 r. Rada Wydziału Teologii zatwierdziła zmianę na stanowisku Dyrektora Instytutu Muzykologii. Ks. dra hab. Ireneusza Pawlaka zastąpił o. dr hab. Józef Ścibor, co jednogłośnie zaakceptował Senat KUL 28 czerwca tego roku ${ }^{33}$. $\mathrm{Na}$ pierwsze lata sprawowania funkcji przypadł szereg ważnych przemian, m.in. „sekularyzacja” kierunku i wprowadzenie regulacji dotyczących programu, tak by muzykologia na KUL odpowiadała programom kształcenia innych kierunków tego typu w Polsce, przy jednoczesnym zachowaniu unikatowej dwuobszarowości kształcenia, polegającej na połączeniu wiedzy teoretycznej z praktyką muzyczną, niezbędną dla właściwej formacji muzyków kościelnych.

Rozbudowywano także strukturę organizacyjną Instytutu, zwiększając kadrę naukowo-dydaktyczną i powołując do życia nowe jednostki organizacyjne: Katedrę Teorii i Historii Muzyki Średniowiecza (marzec 1992 r. ${ }^{34}$ ) i Katedrę Hermeneutyki Muzycznej (2002 r. $\left.{ }^{35}\right)$.

22 czerwca 1995 r. Rada Wydziału Teologii powołała o. Ścibora na stanowisko profesora nadzwyczajnego, które objął na 5 lat z dniem 1 lipca. W ocenie dorobku ks. prof. Bolesław Bartkowski notował: „Znaczenie i doniosłość dorobku naukowego zarówno w aspekcie merytorycznym, jak i systematyzacyjnym muzykologii, szeroka działalność dydaktyczna i organizacyjna, stanowią - moim zdaniem bardzo dobrą podstawę do ubiegania się o stanowisko profesora nadzwyczajnego w Katolickim Uniwersytecie Lubelskim w Lublinie" ${ }^{\prime 36}$.

Ważną misją, która stanęła przed dyrektorem IM KUL, było przygotowanie nowej siedziby jednostki. W 2001 r. muzykologia przeprowadziła się na X piętro Collegium Ioannis Pauli II, które zostało dostosowane do potrzeb dydaktycznych muzykologii. Znalazły się tam nie tylko pomieszczenia dla personelu naukowego, ale także kilkanaście sal ćwiczeniowych, wyposażonych w pianina, fisharmonie, organy elektroniczne i piszczałkowe, z których liczne kupowano w okresie spra-

${ }_{32}$ Tamże, Protokót z kolokwium habilitacyjnego 29.11.1990; tamże, Protokót z posiedzenia Senatu Akademickiego KUL 26.01.1991.

${ }^{33}$ Tamże, List do Rektora KUL z 20.06.1991; tamże, Protokót z posiedzenia Senatu KUL z 28.06.1991.

${ }^{34}$ Tamże, Pismo do Senatu KUL z 4.03.1992; tamże, Protokót z posiedzenia Senatu KUL $z$ 28.03.1992.

35 Por. A. GŁadysz, Instytut Muzykologii, w: S. Nowosad, J. Mastej (red.), 100 lat Teologii na KUL, Lublin 2018, s. 166-167.

${ }^{36}$ AU KUL, sygn. A-887, Ścibor Józef Paweł, cz. 2, Ocena dorobku z 20.06.1995. 
wowania funkcji dyrektora przez o. J. Ścibora, a także nowoczesne studio nagrań, powstałe pod okiem o. Juliana Śmierciaka ${ }^{37}$.

O. Ścibor uczestniczył także i dbał organizacyjnie o przygotowywanie tradycyjnych spotkań, m.in. uroczystości cecyliańskich, spotkań opłatkowych i innych ${ }^{38}$. W 2001 r. otrzymał tytuł profesora zwyczajnego nauk teologicznych ${ }^{39}$.

W 2002 r. wraz z dr. Jackiem Piechem i art. szt. muz. Iwoną Sawulską wszedł w skład zespołu przygotowującego kierunek „muzykologia” do akredytacji. Pozytywny wynik kontroli przyczynił się do przyznania przez Rektora KUL nagrody zespołowej II stopnia ${ }^{40}$. Było to jedno z ostatnich dzieł o. Ścibora w Instytucie Muzykologii KUL.

Po niespełna dwunastu latach sprawowania funkcji o. prof. Józef Ścibor złożył rezygnację ze stanowiska dyrektora IM KUL, która została przyjęta na posiedzeniu Rady Wydziału Teologii 25 lutego 2003 r. Na jego następcę powołano ks. prof. Józefa Pawlaka ${ }^{41}$.

Na emeryturze pozostawał aktywny społecznie, zwłaszcza jako członek Towarzystwa Naukowego KUL, członek Rady Naukowej Instytutu Jana Pawła II oraz recenzent i doradca. Do ostatnich chwil życia wspominał czasy pracy na KUL i wracał pamięcią do swoich studentów i Instytutu.

Swoistą klamrą wieńczącą ponad półwiecze troski zmarłego profesora o IM KUL było przekazanie przez o. dra Janusza Soka, przełożonego Warszawskiej Prowincji Redemptorystów, muzykologicznej i nutowej biblioteki o. Józefa Ścibora Instytutowi Muzykologii KUL, za co w tym miejscu pragnę złożyć serdeczne podziękowania w imieniu władz, pracowników i studentów.

\section{Streszczenie}

Niniejszy artykuł przybliża postać, o. prof. dra hab. Józefa Ścibora - redemptorysty znanego muzykologa, znawcy teorii i historii muzyki średniowiecza, specjalisty w zakresie chorału gregoriańskiego, cenionego organisty i kompozytora muzyki liturgicznej. Zmarły przez niemal całe

37 AU KUL, sygn. A-887, Ścibor Józef Paweł, cz. 2, Ocena dorobku z 20.06.1995, s. 167.

38 Jako Dyrektor rzadko rezygnował z okazji do zabrania głosu i krótkiego komentarza odnośnie do bieżącej sytuacji Instytutu, czy ważniejszych odbytych lub planowanych wydarzeń. Zob. BIM KUL, Kronika Instytutu Muzykologii, t. VI: 1993-2003; bpg.

39 AU KUL, sygn. A-887, Ścibor Józef Pawet, cz. 2, Pismo do Podsekretarza Stanu Sekretarza Komitetu Badań Naukowych z 12.02.2001.

${ }^{40}$ AU KUL, sygn. A-887, Ścibor Józef Paweł, cz. 2, Pismo Rektora KUL z 21.10.2002.

${ }^{41}$ Tamże, Pismo Rady WT do Senatu Akademickiego z 26.02.2003. 
swoje życie związany był z Instytutem Muzykologii KUL. Krótki biogram stanowi zatem nie tylko wspomnienie o o. Ściborze, ale także przyczynek do historii jego uczelni i Instytutu.

Słowa kluczowe: o. Józef Ścibor CSsR, Instytut Muzykologii KUL.

Father, Professor Józef Ścibor (30 January 1930 - 3 June 2017)

Abstract

The article introduces the figure of Redemptorist, rev. prof. Józef Ścibor, a well-known musicologist, expert in the theory and history of medieval music, a specialist in the field of Gregorian chant, and respected organist - composer of liturgical music. Father Ścibor for almost all his life was associated with the Institute of Musicology of The John Paul II Catholic University of Lublin. A short biography is therefore not only a reminder of J. Ścibor, but also a contribution to the history of his University and the Institute.

Keywords: rev. prof. Józef Ścibor CSsR, Institute of Musicology of The John Paul II Catholic University of Lublin.

\section{Aneks \\ Prace dyplomowe napisane i obronione pod kierunkiem o. prof. dr. hab. Józefa Ścibora ${ }^{42}$}

\section{Rozprawy doktorskie:}

1. ks. Robert Bernagiewicz, Recepcja tradycji neumatycznych w notacji Graduatu Wiślickiego z przełomu XIII i XIV w. w świetle neum liquescencentes (1999).

${ }^{42}$ Sporządzono na podstawie: Red., Wykaz prac magisterskich, „Additamenta Musicologica Lublinensia” 2 (2006), s. 55-90; Red., Wykaz prac doktorskich, „Additamenta Musicologica Lublinensia” 2 (2006), s. 91-94. 
2. Jacek Piech, Antyfony w Antyfonarzu kieleckim z 1372 roku w świetle tonariuszy (2001).

3. ks. Krzysztof Borowiec, Cysterskie dzieło odnowy choratu. Teoria - praktyka śpiewów - aspekty estetyczne (2005).

\section{Prace magisterskie:}

1. Gabriela Juros, Analiza muzykologiczna graduatu dominikańskiego z XIV w. pochodzacego z klasztoru $w$ Jarostawiu, przechowywanego w Archiwum OO. Dominikanów w Krakowie (sygn. B. 1 L) (1987).

2. Iwona Pardon, Analiza muzykologiczna Graduatu cysterskiego z XIV wieku pochodzacego z klasztoru w Paradyżu, przechowywanego w Archiwum Archidiecezjalnym w Poznaniu (sygn. ms 69) (1988).

3. Anna Grodziewicz, Antyfony piatego i szóstego modus w Psatterzu krakowskim z $1716 r$. (1992).

4. Beata Madej, Antyfony trzeciego i czwartego modus w Psalterzu krakowskim $z 1716 r$. (1992).

5. Agnieszka Pachulska, Antyfony siódmego i ósmego modus w Psatterzu krakowskim z $1716 r$. (1992).

6. Jacek Piech, Antyfony pierwszego i drugiego modus w Psatterzu krakowskim z 1716 (studium muzykologiczne) (1993).

7. Katarzyna Grochowska, Hymny świateczne w Psatterzu krakowskim z 1716 r. Studium muzykologiczne (1994).

8. Edyta Grzyb, Responsoria brevia w Psatterzu krakowskim z 1716 r. Studium muzykologiczne (1995).

9. Barbara Pudelska, Graduat Wiślicki z Biblioteki Seminarium Duchownego w Kielcach, sygn. RL 1 jako przedmiot badań muzykologicznych (1995).

10. Ewa Stec, Hymny ferialne w Psatterzu krakowskim z 1716 r. (1995).

11. Anna Cichoń, Psalmy w Psatterzu krakowskim z 1716 r. Studium muzykologiczne (1996).

12. Stanisław Tulik, Łacińskie antyfony - typy jako formuly intonacyjne choratu gregoriańskiego (1998).

13. Joanna Usidus, ,De Cantu Chorali” w „Clericus (...) Instructus”. Wilno 1760 (1998).

14. ks. Krzysztof Borowiec, Antyfony ferialne w cysterskiej wersji choralu w przekazie „Psalterium Cistersiense” (Westmalle 1956) (1999). 
15. Aleksandra Gotowicka, Starożytne formuly echematyczne jako formuly intonacyjne choratu gregoriańskiego (1999).

16. Wojciech Rysiewicz, Inwitatoria w Antyfonarzu Kieleckim z 1372 r. Studium liturgiczno-muzykologiczne (1999).

17. Aleksandra Skowrońska, „Neumata” jako melodyczne wzorce choratu gregoriańskiego (1999).

18. Agnieszka Krajewska, „Te Deum laudamus” we wspótczesnych księgach choratowych (2000).

19. Barbara Szyndler, Antyfony ferialne w dominikańskiej wersji chorału w przekazie Antifonarium Ordinis Praedicatorum, Roma 1933 (2001).

20. Katarzyna Jakoniuk, Znaczenie tonariuszy tacińskich w praktyce i teorii choratu gregoriańskiego (2002).

21. Joanna Szafran-Biały, Antyfony ferialne $w$ „Antifonarium monasticum secundum traditionem Helveticae Congregationis Benedictinae" (Engelberg 1943) (2002).

22. Katarzyna Zając, Śpiew liturgiczny Zakonu Braci Mniejszych Konwentualnych w świetle Cantus Ritualis Romano-Seraphici Romae 1943 (2002).

23. Agnieszka Żarska, Responsoria krótkie w Proprium de Tempore Antyfonarza Sióstr Norbertanek z Imbramowic (2002).

\section{Bibliografia}

\section{Źródła:}

Archiwum Uniwersyteckie KUL, Akta personalne pracowników, sygn. A-887, Ścibor Józef Paweł, cz. 1-2.

Archiwum Uniwersyteckie KUL, Akta personalne studentów, sygn. T-15639, Ścibor Józef Paweł.

Biblioteka Instytutu Muzykologii KUL, Kronika Instytutu Muzykologii Kościelnej przy Wydziale Teologii KUL, t. I: 1956-1967.

Biblioteka Instytutu Muzykologii KUL, Kronika Instytutu Muzykologii Kościelnej KUL, t. III: 1969-1974.

Biblioteka Instytutu Muzykologii KUL, Kronika działalności Koła Naukowego I.M.K., t. IV: 1974-1980.

Biblioteka Instytutu Muzykologii KUL, Kronika działalności Koła Naukowego I.M.K., t. V: 1981-1983. 
Biblioteka Instytutu Muzykologii KUL, Kronika Instytutu Muzykologii, t. VI: 1993-2003.

\section{Literatura:}

„Additamenta Musicologica Lublinensia. Rocznik Instytutu Muzykologii Katolickiego Uniwersytetu Lubelskiego" 2 (2006): Instytut Muzykologii Katolickiego Uniwersytetu Lubelskiego 1956-2006.

B. BARTKowsKi, 25 lat Instytutu Muzykologii Kościelnej KUL, „Biuletyn Informacyjny Katolickiego Uniwersytetu Lubelskiego" 11 (1982) nr 1/2, s. 93-100.

A. GŁadysz, Instytut Muzykologii, w: S. Nowosad, J. Mastej (red.), 100 lat Teologii na KUL, Lublin 2018, s. 165-178.

S. Łach, Kronika Wydziału Teologicznego 1944-1968, w: M. RechowicZ I IN. (red), Ksiegga Jubileuszowa 50-lecia Katolickiego Uniwersytetu Lubelskiego, Lublin 1968, s. 143-157.

J. ŚCiBor, Muzykologia Kościelna na Katolickim Uniwersytecie Lubelskim, „Roczniki Teologiczno-Kanoniczne" 15 (1968), z. 3, s. 67-84.

AnDRZeJ GŁadysz - historyk, muzykolog, dr nauk humanistycznych (2015). Zatrudniony w Katedrze Instrumentologii Instytutu Muzykologii KUL, związany również z Pracownią Wojskowo-Historyczną Instytutu Historii KUL. Zainteresowania badawcze koncentrują się wokół historii organów i losach muzyków kościelnych w południowej Polsce, a także instrumentach i ich użytkownikach w wojsku w okresie średniowiecza i nowożytności. Opublikował ponad 70 artykułów naukowych i haseł encyklopedycznych, przygotował redakcyjnie kilka monografii zbiorowych i 4 tomy studenckiego rocznika historyków KUL. Jako wokalista współpracuje z Chórem Akademickim KUL, Filharmonią Lubelską i Teatrem Muzycznym w Lublinie. 